\title{
QUALITY OF INSTITUTION AND ECONOMIC GROWTH OF THE COUNTRIES OF THE EUROPEAN UNION AND THE WESTERN BALKANS
}

\author{
UDC 330.35(4-672EU:497)
}

\author{
Vladimir Kostić ${ }^{\text {, Samir Ljajić }}{ }^{2}$, Slobodan Cvetanović ${ }^{3}$, \\ Vladimir Nedic ${ }^{4}$ \\ ${ }^{1}$ Faculty of Economics Kosovska Mitrovica, Serbia \\ ${ }^{2}$ University of Novi Pazar, Serbia \\ ${ }^{3}$ University of Niš, Faculty of Economics, Serbia, \\ ${ }^{4}$ Technical College of Aplied Studies Kragujevac, Serbia
}

\begin{abstract}
The paper analyzes the intensity of the influence of the quality of institutions according to the data from the World Bank's specialized Worldwide Governance Indicators database on the growth of gross domestic product per capita of 33 countries of Europe through linear and exponential regression analysis for the period from 1996 to 2016. The observed European countries are divided into three groups: 15 European Union member states in 1995; 13 EU member states from 2004, 2007 and 2013, as well as five countries of the Western Balkans that negotiate or have the status of a candidate for EU membership, in the period from 1996 to 2016. The results of the research have shown that the quality of the institutions had a very positive impact on the economic growth of the observed countries of Europe. According to statistics, positive interdependence is the most significant among the Western Balkan countries. The conclusion is that these countries have to pay special attention to the development of institutions in the process of joining the European Union.
\end{abstract}

Key words: institutions; economic growth; European countries, EU15, EU13, countries of the Western Balkans

JEL Classification: O43

Received January 21, 2019 / Accepted March 13, 2019

Corresponding author: Vladimir Nedić

Technical College of Applied Studies Kragujevac, Kosovska 8, 34000 Kragujevac, Serbia

E-mail: vnedic@kg.ac.rs 


\section{INTRODUCTION}

The key issue concerning economic growth and development is why some countries are significantly poorer than others. Although there are many different explanations of this phenomenon, it can be noted that economic science is still far from having a generally accepted explanation of the key drivers of long-term economic growth (Acemoglu, Johnson \& Robinson, 2005).

The most important traditional theories of economic growth did not take into account the importance of institutions in the initiation of economic dynamics (Cvetanovic \& Mladenović, 2015, p. 71; Cvetanović, Kostic \& Milačić, 2016). Neoclassical models of economic growth did not take into consideration the significance of institutions in generating economic growth at all (Acemoglu et al, 2004). In short, in the neoclassical approach, the institutions are marginalized, and the causes of economic growth are sought exclusively among production factors (land, labor, physical capital).

Institutions represent the rules of the game in society, that is, the constraints created by people, which design complex interactions of economic actors in complex processes of creating and exchanging new values (North, 1994, p. 360). The study of economic growth involving institutions has begun with the emergence and affirmation of the theory of endogenous growth since the beginning of the last decade of the previous century. Because of this, institutions create an environment in which the economic activities of individuals and businesses take place.

Bearing in mind the fact that the institutions act with varying intensity on the economic growth of countries of different levels of economic development, the subject of research in this paper is determined in terms of understanding the impact of the quality of institutions on the economic growth of the countries of the European Union and the Western Balkans that are in the stages of accession to this regional economic organization.

The aim of the paper is to create a model of the impact of the component vector (different indicators of institution development) of institutions on economic growth of three groups of selected European countries at different levels of economic development.

The composition of the work is structured in the following way: After the introduction, Section 2 gives an overview of the relevant literature in this area, while section 3 presents the theoretical framework for assessing the quality of institutions based on WGI (The Worldwide Governance Indicators) methodology of the World Bank (WGI project, n.d.) to quantify their impact on the economic growth of the observed countries, the sources of data used in the work are cited, and the paper also provides a more detailed overview of the applied research methodology. The results achieved by the applied model and their discussion are stated in section 4, and in section 5 the conclusion and implications for policy makers as well as for institution-building policies are presented.

\section{REVIEW OF LITERATURE}

Literature primarily points to a positive correlation between the level of institutional development as aggregate size and economic growth. However, the quality of institutions does not have similar effect on economic growth neither in different 
countries, nor at different levels of development of individual economies. This presumably positive contribution of institutions can therefore be seen as an effect of the set of various component indicators of institutional development. In addition, there is the influence of so-called "soft" factors, such as the perception of the institution by the individual, the prevailing social norms and rules, and the broader cultural profile of the particular community we are observing. Very often institutions of very similar characteristics produce different outcomes in some national economies (Alonso \& Garcimartín, 2013).

A growing interest in researching the quality of institutions as a factor of economic growth was initiated by Barro (1991), which included measures of political stability as an assessment of the quality of institutions in the cross-country analysis of long-term growth. Barro observed 98 countries in the period from 1960 to 1985, using the average GDP growth rate as the dependent variable during that period, while as independent variables he took the initial GDP, the initial average number of years of schooling, public spending, market distortions and existing investments. The results of the survey confirmed the existence of a positive link between political stability and economic growth. His research is significant because of the fact that he designed a model of econometric model which was then slightly changed by other researchers. The specificity of that work lies in the fact that he used objective measures as an indicator of the quality of institutions - the number of revolutions and assassinations.

Mauro (1995) used three indicators of the quality of institutions: (1) corruption, (2) the efficiency index of the administration, and (3) the political stability index, and established a positive and statistically significant relationship between these indicators with investments and economic growth.

Knack and Keefer (1995) constructed the quality index of institutions that included "government corruption", "rule of law", "risk of expropriation", "quality of bureaucracy" and "non-recognition of contracts". In their research, the improvement of the index for one standard deviation (12 points on a scale of 50) increases the average annual growth rate of GDP per capita by 1.2 percentage points. In particular, they pointed to the fact that the improvement of the protection of property rights has worked to increase the size of investments and the efficiency of the use of resources.

A large number of authors have concentrated on the relationship of democracy and growth. Tavares and Wacziarg (2001) have found that democracy increases the accumulation of human capital, but it reduces the investment in physical capital, so the overall impact on growth is moderately negative.

According to the findings so far, the institutions are a very important determinant of investments, sustainable development, transition processes and economic turbulences of national and regional economies, and more and more of the global economies (Rodrik, 2008; Van den Berg, 2016; North, 1994). Empirical research shows a big, real and potential role of institutions which becomes obvious in evident and very important differences in the rate of capital accumulation, education, available human resources, variations in productivity of labor, which in the end cause enormous differences in the income of the population of individual regions (where the term region can be observed in a very broad sense). It is quite unquestionable that, for example, the rule of law, political stability and low level of corruption positively affect economic growth (Haggard \& 
Tiede, 2011; Rodrik, Subramanian \& Trebbi, 2004). Also, a large number of analysts are exploring the driving potential of the private ownership institution as the key cornerstone of modern liberal capitalism to long-term sustainable economic growth (Acemoglu, Johnson \& Robinson, 2005; De Haan \& Sturm, 2000).

Alonso and Garcimartin (2013) have looked at the role of the stage of economic development of a particular economy in determining the character and intensity of the effects of institutional development. In the work they detect a certain positive spiral effect when the achieved economic development determines the qualitative change of institutions, which further promote further economic growth. Nawaz (2014), as well as Valeriani and Peluso (2011), also found in their researches that the intensity of the influence of institutions on economic growth is, to a large extent, the function of the economic development phase in which the observed country is located. Their conclusion is that institutions are developing better in developed countries than in developing countries.

\section{Methodology}

The work is based on:

- Measuring the quality of institutions - according to data from the World Bank's specialized database World Bank Governance Indicators (WGI),

- determining the degree of influence of the quality of institutions on economic growth,

- answering the question that refers to how much and how the degree of development of institutions affects economic development

Institutions are represented by the indicators of the Worldwide Governance Indicators in six dimensions (Figure 1).

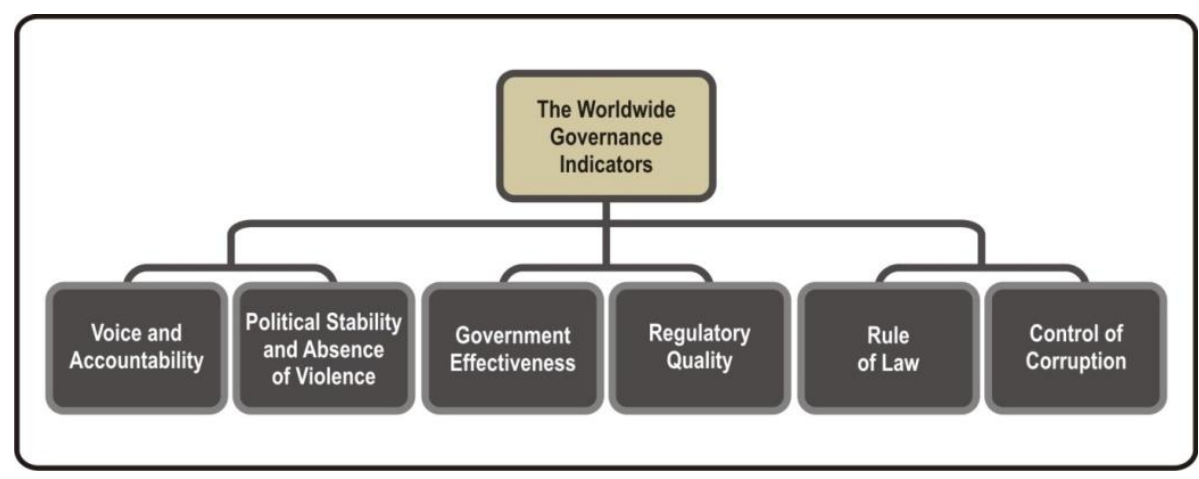

Fig. 1 Six dimensions of WGI

Source: (WGI project).

WGI is a tool developed by the World Bank to monitor aggregate and individual indicators of the achieved level of state administration institutions and covers more than 200 countries in the period from 1996 to 2016. These aggregate indicators combine the 
views of a large number of businesses, individuals and professionals surveyed in industrial and developing countries. They are based on over 30 individual sources of data produced by various research institutes, think tanks, non-governmental organizations, international organizations and private companies.

State planning and administration represent the broadest framework of a society in which both social and economic activities take place. State administration is broadly defined by the tradition and institutions that are exercising authority in the country. This includes a process by which governments are elected, supervised and replaced, and also the government's ability to formulate and implement effectively sound policies and respect for citizens and the state for all institutions that regulate economic and social interactions between them.

The influence of institutional quality on the economic growth of selected European countries measured by the size of gross domestic product per capita is quantified by means of a single correlation and regression analysis. The survey covers the period from 1996 to 2016.

The following two hypotheses are set:

H1 - Quality level of institutions has a positive impact on economic growth.

$\mathrm{H} 2$ - Significance and intensity of positive impact of institution quality is inversely proportional to the achieved level of GDP pc of the observed country groups.

In order to test $\mathrm{H} 1$ and $\mathrm{H} 2$, the appropriate regression model (linear and exponential regression) for the time series in the period from 1996 to 2016 was constructed, where the value of WGI - Institution was taken as an independent variable (the average value of all 6 defined indicators of the quality of institutions shown in Fig. 1). It is a composite indicator because it represents the aggregated value of the corresponding indicators that describe the state of the Institutions. The movement of economic growth, as dependent variables, is monitored by the size of Gross domestic product per capita in current US dollars. The degree of interdependence of institutional quality and economic growth, GDP per capita (in US \$), was examined through a single regression and correlation analysis using (1) linear and (2) exponential functional dependencies. The WGI model of impact on GDP per capita based on formulas 1 and 2 was made:

Linear model: $\mathrm{Yt}=\mathrm{a}+\mathrm{bXt}$

where:

Exponential model: $\mathrm{Yt}=\mathrm{a}^{*} \mathrm{ebXt}$

$\mathrm{a}, \mathrm{b}$ - constants of the linear / exponential model;

$\mathrm{x}$ - independent (exogenous) variable (WGI);

$\mathrm{y}$ - dependent (endogenous) variable (GDP per capita);

$\mathrm{t}$-years of data.

\section{RESULTS OF THE RESEARCH AND THEIR OUTCOME}

EU countries are divided into two groups: a) EU15 countries and b) the remaining 13 EU countries. The EU15 group consists of: a) founding members (France, Germany, Italy, Belgium, the Netherlands, Luxembourg, countries that became members of the EU 
in the first enlargement in 1973 (UK, Denmark, Ireland), countries that became members of the EU in another enlargement in 1981 (Greece), countries that became members of the EU in the third enlargement in 1986 (Spain, Portugal) and countries that became members of the EU in the fourth enlargement in 1995 (Austria, Finland, Sweden). EU15 are the most economically developed countries in Europe.

The group of the remaining 13 EU countries consists of: a) countries that became members of the EU in the fifth enlargement of the EU in 2004 (Hungary, Slovak Republic, Poland, Latvia, Cyprus, Lithuania, Czech Republic, Slovenia, Estonia, Malta); countries that joined the EU in the sixth enlargement in 2010 (Bulgaria and Romania) and the country that became a member in the seventh enlargement in 2013 (Croatia).

Two countries from five Western Balkan countries are negotiating membership (Montenegro and Serbia), two are candidates (Albania and North Macedonia), while Bosnia and Herzegovina is a potential candidate for EU membership.

Table 1 Average GDP values of pc analyzed groups of countries in the observed period

\begin{tabular}{lccl}
\hline Year & West Balkan & EU13 & EU15 \\
\hline 1996 & 3,846 & 9,674 & 22,599 \\
1998 & 4,486 & 10,830 & 24,911 \\
2000 & 5,102 & 12,165 & 28,390 \\
2002 & 5,744 & 14,002 & 30,813 \\
2003 & 6,041 & 14,856 & 31,433 \\
2004 & 6,628 & 15,996 & 33,112 \\
2005 & 7,216 & 17,203 & 34,364 \\
2006 & 8,512 & 19,004 & 37,500 \\
2007 & 9,515 & 20,991 & 39,676 \\
2008 & 10,678 & 22,683 & 41,011 \\
2009 & 10,716 & 21,779 & 39,647 \\
2010 & 11,194 & 22,674 & 40,848 \\
2011 & 11,832 & 24,044 & 42,393 \\
2012 & 11,904 & 24,704 & 42,845 \\
2013 & 12,537 & 25,716 & 44,299 \\
2014 & 12,987 & 26,759 & 45,619 \\
2015 & 13,349 & 27,593 & 47,532 \\
2016 & 14,160 & 28,732 & 48,502 \\
\hline \multicolumn{4}{c}{ Source World Development Indicators. (n.d.) }
\end{tabular}

Figure 2 illustrates the differences in the average GDP pc of the three observed groups of countries in the period from 1996 to 2016. 


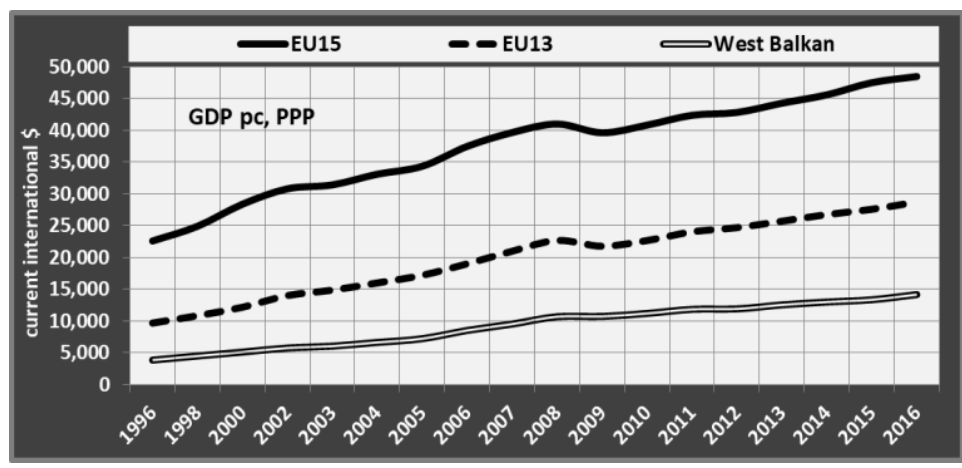

Fig. 2 Movement of average GDP pc in the observed period Source: World Development Indicators. (n.d.)

According to the results of the conducted regression analysis presented in Tables 2 and 3, two models of linear and exponential form were obtained

Table 2 Summary linear correlation statistics for the three observed groups of countries

\begin{tabular}{|c|c|c|c|}
\hline \multirow[t]{2}{*}{ Variables } & (1) EU15 & (2) EU13 & (3) Z. Balkan \\
\hline & \multicolumn{3}{|c|}{ GDPpc as Dependent variable: $\boldsymbol{y}$} \\
\hline WGIAverge as $\mathrm{x}$ & $552.2 * * *$ & $452.5 * * *$ & $291.3 * * *$ \\
\hline Constant & $\begin{array}{l}-11,081 \\
(7,780)\end{array}$ & $\begin{array}{c}-12,941 * * * \\
(3,098)\end{array}$ & $\begin{array}{c}-3,109 * * * \\
(1,057)\end{array}$ \\
\hline Observations & 270 & 234 & 88 \\
\hline R-squared & 0.128 & 0.331 & 0.632 \\
\hline Adjusted R-squared & 0.125 & 0.328 & 0.627 \\
\hline F Statistic $(\mathrm{df}=1 ; 268 / 232 / 86)$ & 39.48 & 114.81 & 147.41 \\
\hline
\end{tabular}

$* * * \mathrm{p}<0.01, * * \mathrm{p}<0.05, * \mathrm{p}<0.1 ;$ Standard errors in parentheses

Table 3 Summarized statistics of exponential correlation for the three observed groups of countries

\begin{tabular}{|c|c|c|c|}
\hline \multirow[t]{2}{*}{ Variables } & (1) EU15 & (2) EU13 & (3) Z. Balkan \\
\hline & \multicolumn{3}{|c|}{$\mathrm{Ln}(\mathrm{GDPpc})$ as Dependent variable: $\boldsymbol{y}$} \\
\hline \multirow{2}{*}{ WGIAverge as $\mathrm{x}$} & $0.0132 * * *$ & $0.0269 * * *$ & $0.0346 * * *$ \\
\hline & $(0.00198)$ & $(0.00244)$ & $(0.00298)$ \\
\hline \multirow[t]{2}{*}{ Constant } & $9.315 * * *$ & $7.856 * * *$ & $7.584 * * *$ \\
\hline & $(0.176)$ & $(0.179)$ & $(0.131)$ \\
\hline Observations & 270 & 234 & 88 \\
\hline R-squared & 0.141 & 0.344 & 0.611 \\
\hline Adjusted R-squared & 0.138 & 0.341 & 0.606 \\
\hline F Statistic $(\mathrm{df}=1 ; 268 / 232 / 86)$ & 44.03 & 121.71 & 134.81 \\
\hline
\end{tabular}


Graphic interpretation of the linear and exponential regression model of the influence of institution and economic growth is shown in Figures 3, 4 and 5.

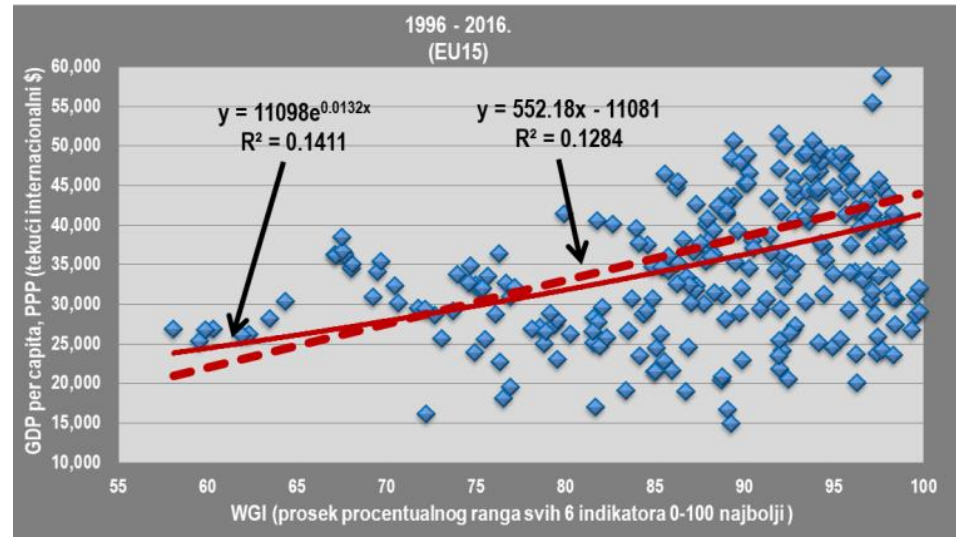

Fig. 3 The dependence of GDP per capita on the degree of development of the Institution (WGI) for the EU15 countries

By the analysis of the relationship shown in Figure 2 (for EU 15), the Pearson coefficient of correlation $\mathrm{R}=0.358$ for linear, or $\mathrm{R}=0.376$ was determined, which is more than the limit for the number of degrees of freedom $n=268$ and the significance level $\mathrm{p}<0.01$.

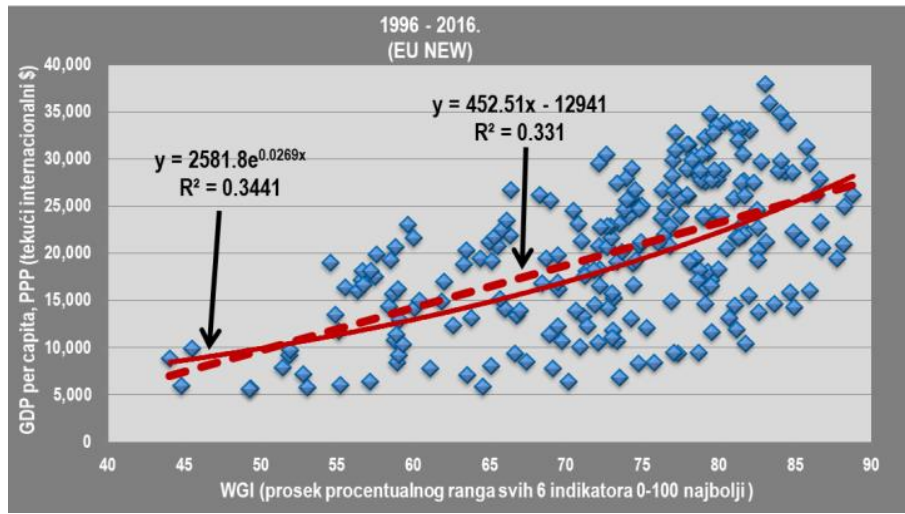

Fig. 4 Dependence of GDP per capita on the level of institution building (WGI) for the EU13 countries

The analysis of the relationship shown in Figure 4 (for EU 13) determined the Pearson correlation coefficient $\mathrm{R}=0.575$ for linear or $\mathrm{R}=0.587$, which is more than the limit for the number of degrees of freedom $n=232$ and the significance level $p<0.01$. 


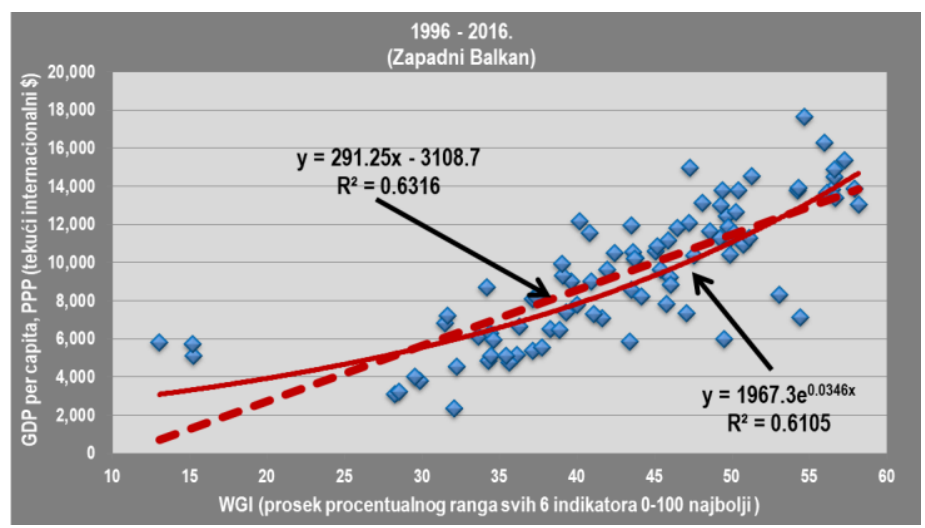

Fig. 5 The dependence of GDP per capita on the level of institution building (WGI) for the countries of the Western Balkans

The analysis of the relationship shown in Figure 4 (for the five countries of the Western Balkans) determined the value of the Pearson correlation coefficient $\mathrm{R}=0.795$ for linear, i.e. $\mathrm{R}=0.781$ for the exponential, which is more than the limit for the number of degrees of freedom $n=86$ and the level of significance $p<0.01$.

It is shown that both applied regression models give approximately the same degree of interdependence of the observed variables for all three groups of analyzed European countries. We are of the opinion that the potential of the relationship between the observed variables Institution and GDP pc evidently exists, and that it is particularly evident in the countries of the Western Balkans.

The obtained results indicate:

The change of the achieved level of institution development in the period from 1996 to 2016 had a statistically significant impact on the economic growth measured at the level of GDP pc of all three groups of countries observed, EU15, EU13 and the Western Balkan countries ( $\mathrm{p}<0.01)$. By this the hypothesis $\mathrm{H} 1$ is confirmed.

A comparative analysis of the results obtained at the level of the three observed groups of countries in Europe shows that:

(1) For the EU15 countries, there is a statistical significance of the positive impact of the quality of institutions on economic growth in both applied correlation models (Adjusted R2 $=0.125$ in linear, or 0.138 in the exponential correlation model). It is considered that according to the assumed model, the variations of the independent variable WGI explain about $13 \%$ of the total variations in the economic growth of the EU15, under the assumption of the unchanged values of other explanatory variables.

(2) For the EU13 group, there is even more pronounced statistical significance of the positive impact of the development of institutions on economic growth, and also in both of the applied correlation models (Adjusted R2 $=0.328$ in the linear model, and 0.341 in the exponential correlation model). This implies that the assumed model in the EU13 explains about $33 \%$ of variations in economic growth (assuming unchanged values of other explanatory variables).

(3) For the group of Western Balkan countries, there is statistically the most evident significance of the positive impact of institutional development on economic growth, 
which is reflected in the value of Adjusted R-squared of as much as 0.626 in linear and 0.606 in the exponential correlation model (partially, this implies that variations of the variable Institutions explain about $60 \%$ of the total variations in the economic growth of the countries of the Western Balkans in the period from 1996 to 2016, assuming unchanged values of other explanatory variables);

(4) The intensities of the impact of the quality of institutions on economic growth vary both among the group of countries and the correlation function in the model. The linear model shows stronger intensities of the positive influence of the development of institutions, which is proportional to the achieved GDP pc of the observed groups of countries (the intensity of the impact of the independent variable on the dependent for the EU15 is 552.2, the EU13 is 452.5, and the Western Balkans is 291.3). In the case of the exponential model the situation is different. The intensities of the positive influence of the development of institutions are inversely proportional to the achieved level of GDP pc of the observed groups of countries. (The intensity of the impact of an independent variable on the dependent for the EU15 is 0.0132; for the EU13 it is 0.0269 and 0.0346 for the Western Balkan countries).

(5) It is noted that for the group of Western Balkan countries, the linear regression model better describes the nature of the influence of institutional development on economic growth (Adjusted R-squared 0.627 for a linear model is greater than 0.606 in the exponential model), while in EU13 (Adjusted R -squared 0.341 for the exponential model in relation to the 0.328 for the linear model), and especially the EU15 (Adjusted R-squared 0.138 in the exponential model with respect to 0.125 for the linear model), the exponential model shows slightly better results.

\section{CONCLUSION}

The results of the survey of the set regression models on the observed sample of European countries confirmed the validity of the hypothesis H1. Also, the potential of $\mathrm{H} 2$ hypothesis about the nature of the influence of the independent variable $\mathrm{x}$ (institution development) on the dependent variable y (GDP per capita) has been confirmed. Based on the obtained values in the applied regression models (linear and exponential), the conclusion is that the dominant and approximately linear influence of the quality of institutions on economic growth can be expected at a stage in which the economic growth is based on the efficiency-driven stage to which they belong and Institutions (the case of the Western Balkan countries), while after the end of this phase (in the whole case of the EU15 and partly the case of the remaining EU13 countries), the significance of the impact of Institutions is significantly decreasing. In simple terms and in line with $\mathrm{H} 2$ hypothesis, countries at lower levels of economic development can achieve a more significant benefit by speeding up the quality of institutions.

In order to better understand the impact of institutional development on the economic growth of countries, further research could go towards testing, which takes into account the impact of the achieved level of individual indicators of the composite indicator WGI on economic growth quantified by the GDP per capita indicator. All this implies the imperative that the economic growth of the countries of the Western Balkans must still largely be based on the accelerated construction of efficient institutions. The basic message is that these countries need to improve their own institutional reform 
strategies as well as to work on the development of institutions. This undoubtedly represents a necessary condition for their further sustainable economic development.

\section{REFERENCES}

Acemoglu, D., Johnson, S. \& Robinson, J. (2005). The Rise of Europe: Atlantic Trade. Institutional Change, and Economic Growth, 95 (3) 546-579.

Acemoglu, D., Johnson, S., Robinson, J. A. \& Yared, P. (2005). From education to democracy ?. American Economic Review, 95 (2), 44-49.

Alonso, J. \& Garcimartin, C. (2013). The Determinants of Institutional Quality. More on the Debate, Journal of International Development, 25 (2), 206-226.

Barro, R. (1991). Economic Growth in a Cross Section of Countries. The Quarterly Journal of Economics, 106 (2), 407-443.

Cvetanovic, S. \& Mladenovic, I. (2015). Economics of Capital and Financing of Development. Nis: own edition.

Cvetanovic, S. Kostic, V. \& Milacic, Lj. (2016). European Union: Development, Constitutional Design and Common Economic Policies. Kosovska Mitrovica: Faculty of Economics, University of Pristina.

De Haan, J. \& Sturm, J. E. (2000). On the relationship between economic freedom and economic growth. European Journal of Political Economy, 16 (2), 215-241.

Haggard, S. \& Tiede, L.B. (2011). The rule of law and economic growth: where are we?. World Development, 39 (5), 673-685

Knack S. \& Keefer, P. (1995). Institutions and Economic Performance: Cross-Country Tests Using Alternative Institutional Measures. Economics and Politics, 7 (3), 207-227.

Mauro, P. (1995). Corruption and Growth. The Quarterly Journal of Economics, 110 (3), 681-712.

Nawaz, S. (2015). Growth effects of institutions: A disaggregated analysis. Economic Modeling, 45, 118-126.

North, D. (1994). Economic Performance Through Time. The American Economic Review, 84 (3) 359-368.

Rodrik, D. (2008). "Thinking about Governance" in D. North et al., Governance, Growth and Development Decision Making. Washington, DC: World Bank, pp. 17-24.

Rodrik, D., Subramanian, A. \& Trebbi, F. (2004). Institutions Rule: The Primacy of Institutions, Geography and Integration in Economic Development. Journal of Economic Growth, 9, 131-165.

Tavares, J. \& Wacziarg, R. (2001). How democracy affects growth. European Economic Review, 45 (8), 1341-1378.

Valeriani, E. \& Peluso, S. (2011). The impact of institutional quality on economic growth and development: An empirical study. Journal of Knowledge Management, Economics and Information Technology, 1 (6), 1-25.

Van den Berg, H. (2016). Economic growth and development. World Scientific Publishing Company.

World Development Indicators. (n.d.). Retrieved January 3, 2019, from https://databank.worldbank.org/data/ source/world-development-indicators. World Bank Databank.

WGI project. (n.d.). The Worldwide Governance Indicators. Retrieved January 11, 2019, from http://info.worldbank. org/governance/wgi/\#home. World Bank.

\section{KVALITET INSTITUCIJA I EKONOMSKI RAST ZEMALJA EVROPSKE UNIJE I ZAPADNOG BALKANA}

U radu je ispitavan intenzitet uticaja kvaliteta institucija prema podacima iz specijalizovane baze Svetske banke Worldwide Governance Indicators na rast bruto domaćeg proizvoda per capita 33 zemlje Evrope putem linearne i eksponencijalne regresione analize za vremenski period 1996-2016. Sagledavane zemlje Evrope su razvrstane u tri grupe: 15 zemalja članica Evropske unije zaključlno sa 1995. godinom; 13 zemalja EU članica iz 2004, 2007. i 2013. godine, kao $i$ pet zemalja Zapadnog Balkana koje pregovaraju ili imaju status kandidata za članstvo u EU, u periodu 1996-2016. Rezultati istraživanja su pokazali da je kvalitet institucija imao izrazito pozitivan uticaj na ekonomski rast sagledavanih zemalja Evrope. Pozitivna međuzavisnost je statistički najizraženija kod grupacije zemalja Zapadnog Balkana. Zaključak je da ove zemlje moraju u procesu pridruživanja Evropskoj uniji posebnu pažnju posvetiti razvoju institucija.

Ključne reči: institucije, ekonomski rast, evropske zemlje, EU15, EU13, zemlje Zapadnog

$$
\text { Balkana }
$$

